\title{
Menumbuhkan Jiwa Entrepreneur Mahasiswa PPKN Melalui Mata Kuliah Kewirausahaan
}

\author{
Neneng Rika Jazilatul Kholidah \\ IKIP PGRI BOJONEGORO \\ J1. Panglima Polim No.46 Bojonegoro \\ jazilarika@yahoo.co.id
}

\begin{abstract}
The increase of bachelor graduates will increase competition in looking for work and the lack of jobs will increase the number of unemployment lists. Being unemployed is undesirable because of self-harm and unbeneficial to the surrounding community. This study was aimed to determine the importance of entrepreneurship courses for students in the civics study program. This study used a qualitative method. The data collection techniques were observation, interview, and documentation. The informants were 25 students who have taken entrepreneurship courses. The results showed that the existence of entrepreneurship courses in higher education can foster entrepreneurial spirit by instilling knowledge and interest in entrepreneurship, fostering confidence and skills in entrepreneurship, increasing motivation to become young entrepreneurs.
\end{abstract}

Keywords: Students, civics, entrepreneurship

\begin{abstract}
Abstrak
Semakin bertambahnya lulusan sarjana akan semakin ketat persaingan dalam mencari pekerjaan serta kurangnya lapanga pekerjaan akan menambah jumlah daftar pengangguran. Menjadi penggangguran adalah sesuatu hal yang tidak banyak orang lain inginkan, karena selain merugikan diri sendiri juga tidak bermanfaat bagi masyarakat sekitar. Penelitian ini bertujuan untuk mengetahui pentingnya mata kuliah kewirausahaan bagi mahasiswa pada progam studi PPKN. Penelitian ini menggunakan metode kualitatif. Teknik pengumpulan data yaitu observasi, wawancara dan dokumentasi. Infoman sejumlah 25 mahasisa yang sudah mengikuti mata kuliah kewirausahaan. Hasilnya menunjukkan bahwa dengan adanya mata kuliah kewirausahaan di perguruan tinggi mampu menumbuhkan jiwa entrepreneur dengan cara menanamkan pengetahuan dan minat dalam berwirausaha, menumbuhkan kepercayaan diri dan keterampilan dalam berwirausaha, meningkatkan motivasi untuk menjadi young entrepreneur.
\end{abstract}

Kata kunci : Mahasiswa, PPKn, kewirausahaan 


\section{PENDAHULUAN}

Semakin bertambahnya lulusan sarjana akan semakin ketat persaingan dalam mencari pekerjaan serta kurangnya lapanga pekerjaan akan menambah jumlah daftar pengangguran. Menjadi penggangguran adalah sesuatu hal yang tidak banyak orang lain inginkan, karena selain merugikan diri sendiri juga tidak bermanfaat bagi masyarakat sekitar. Dengan menyatukan sumber daya manusia yang sudah dimiliki serta sumber daya alam yang ada di sekitar. Maka dengan penyatuan tersebut mampu menghasilkan sesuatu yang baru dengan dukungan adanya sebuah inovasi serta kreatifitas. Sehingga dengan memanfaatkan potensi tersebut mampu memberikan manfaat untuk orang lain. Dari data Badan Pusat Statistika (BPS) Provinsi Jawa Timur bahwasanya dalam setahun terakhir, pengangguran berkurang 10,26 ribu orang, sedangkan TPT turun menjadi 3,69 persen pada Februari 2020. Meski demikian tidak menutup kemungkinan untuk bisa berubah sewaktu-waktu,ditengahtengah masa pandemi ini masyarakat sangat khawatir jika angka pengangguran menjadi meningkat. Menurut (Saiman,2014) Pengangguran-pengangguran ini bukanlah orang yang tidak memiliki pengetahuan dan keterampilan,melainkan karena mereka ingin menjadi pekerja, sementara kesempatan kerja terbatas. Hal sependapat juga disampaikan oleh Handayani dan Suyanto (2016) pengangguran ini biasanya disebabkan kurangnya lapangan pekerjaan bagi para lulusan sarjana-sarjana muda tersebut padahal jika mereka memiliki bekal pengetahuan,motivasi dan modal untuk berwirausaha,mungkin hanya sedikit pengangguran ditengah-tengah banyaknya jumlah sarjana-sarjana muda tiap tahunnya.

Krisis global yang menginduk kepada kapitalisme mengakibatkan semakin tingginya angka pengangguran di sebuah Negara. Lalu ke mana lagi akan mencari solusi atas tingginya pengangguran para sarjana? Pendidikan kewirausahaan yang diberikan di perguruan tinggi harus berjalan secara berkesinambungan dan menjadi point yang tidak bisa terpisahkan dari seluruh proses pendidikan di perguruan tinggi. Hal tersebut tersebut perlu dilakukan untuk mengatasi pengangguran terdidik yang terus meningkat setiap tahunnya dengan menyiapkan lulusan perguruan tinggi yang tidak hanya berorientasi sebagai pencari kerja, tetapi juga sebagai pencipta lapangan kerja.

Ven Sriram dan Tigineh (2010)" Entrepreneurship is laudid as an engine of economic development and job creation ".Tidak semua lulusan sarjana pendidikan akan terjun ke dunia pendidikan karena beberapa sebab. Secara realita, dalam diri mereka ada beberapa pilihan yang diambil selain menjadi seorang guru yaitu menjadi karyawan perusahaan swasta, menjadi pengangguran, dikarenakan persaingan dunia kerja semakin ketat dan yang terakhir adalah membuka usaha sendiri (berwirausaha). Menurut Farid (2017) Mengubah mental dari pencari kerja menjadi pembuka lapangan pekerjaan bukan pekerjaan mudah. Sedangkan Siswo Wiratno (2012) Perubahan tidak dapat dilakukan secara instan tetapi harus dilakukan secara bertahap, dengan memberikan contoh-contoh yang diberikan pada masyarakat. beberapa pembekalan program kewirausahaan yand dapat dilakukan di perguruan tinggi dalam mempersiapkan para lulusannya sebagai calon wirausahabaru sebgai berikut:

1. Program Mahasiswa Wirausaha (PMW)

2. Program Mahasiswa Kewirausahaan (KWU)

3. Program Magang Kewirausahaan (MKU)

4. Pogram Kuliah Kerja Usaha (KKU)

5. Inkubator Wirausaha Baru (IBWUB)

Perguruan tinggi yang berminat menjadi wirausahawan dengan biaya terjangkau selama jangka waktu tertentu (2-3 tahun ) 
Selain itu Dikti juga menawarkan Program Kreativitas Mahasiswa (PKM), dimana dalam porgram tersebut semua mahasiswa memiliki peluang untuk mengikuti, sehingga hal ini memacu mahasiswa dengan background pendidikan dimana selain menjadi calon guru mahasiswa juga diberikan motivasi untuk berwirausaha,di program studi Pendidikan Pancasila dan Kewarganegaraan mata kuliah kewirausahaan menjadi Mata Kuliah Perilaku Berkarya (MPB) yang diberikan pada semester 8. Lembaga pendidikan memiliki peran serta tanggung jawab untuk mengatasi masalah pengangguran dengan memberikan mata kuliah kewirausahaan dengan ini diharapkan mampu menumbuhkan jiwa entrepreneur bagi mahasiswa yang memiliki background pendidikan,pendidikan adalah suatu pengalaman dimana sebuah pengalaman akan memberikan pembelajaran selain itu pengalaman juga mampu membuat diri seseorang untuk berkembang untuk bersikap dewasa. Perguruan Tinggi adalah sebuah wadah bagi mahasiswa mencari pengalaman seluas-luasnya.

Berbicara mengenai kewirausahaan menjadi topik menarik bagi mahasiswa dimana mahasiswa menjadi generasi penerus bangsa dan harus menjadi tonggak kokohnya berdirinya suatu negara. Karena saat ini kita tidak tau apa yang akan terjadi selanjutnya sehingga mahasiswa bisa bekerja profesional selain itu dituntut untuk mampu berfikir secara kreatif saat hidup bermasyarakat dan tidak takut untuk memulai usaha.

Penelitian yang menjadi acuan yaitu Eriawaty (2016) menuliskan tentang peran mata kuliah kewirausahaan dalam menumbuhkan jiwa wirausaha di perguruan tinggi, dapat dilakukan melalui pendidikan, penelitian maupun pengabdian kepada masyarakat. Mata kuliah Kewirausahaan merupakan upaya yang dilakukan dalam menumbuhkan jiwa kewirausahaan mahasiswa. Selain itu, Hasni (2018) menuliskan tentang urgensi pendidikan kewirausahaan dalam menghasilkan wirausahawan muda dari perguruan tinggi, lulusan perguruan tinggi diharapkan memiliki mental wirausaha yang didapatkan dari pendidkan kewirausahaan yaitu sebagai pembuka lapangan pekerjaan, bukan sebagai pencari lapangan pekerjaan.

\section{KAJIAN PUSTAKA}

\section{Entrepreneur}

Menurut Moko P. Astameon (2008) Kata "kewirausahaan" sebagai terjemah dari entrepreneurship dilontarkan pada tahun 1975 dan mulai digunakan di antara anggota kelompok entrepreneur Developmen Program - Development Teknology Centre (EDPDTC), Institut teknologi bandung.

Menurut Geoffrey G. Mendith (2002) kewirausahaan merupakan gambaran dariorang yang memiliki kemampuan melihat dan menilai kesempatan-kesempatan bisnis, mengumpulkan sumber daya yang dibutuhkan untuk mengambil keuntungan daripadanya, serta mengambil tindakan yang tepat guna memastikan kesuksesan.

Secara umum tahap-tahap melakukan wirausaha yaitu:

a. Tahap memulai, tahap dimana seseorang berniat melakukan usaha mempersiapkan segala sesuatu yang diperlukan, diawali dengan melihat peluang baru yang mungkin untuk membuka usaha baru.

b. Tahap melaksanakan usaha, tahap ini seorang entrepereneur mengelola berbagai aspek yang terkait dengan usahanya, mencangkup aspek-aspek: pembiayaan, SDM, kepemilikan, organisasi, kepemimpinan yang meliputi bagaimana resiko dan mengembil keputusan, pemasaran, dan melakukan evaluasi. 
c. Mempertahankan usaha, tahap dimana entrepreneur berdasarkan hasil yang telah dicapai melakukan analisis perkembangan yang dicapai untuk ditindaklanjuti sesuai dengan kondisi yang dihadapi.

d. Mengembangkan usaha, tahap dimana jika hasil yang diperoleh positif, mengalami perkembangan, dan dapat bertahan maka perluasan usaha menjadi salah satu pilihan yang mungkin diambil.

Menurut Kasmir (2011) Secara sederhana arti entrepreneur adalah orang yang berjiwa berani mengambil resiko untuk membuka usaha dalam berbagai kesempatan.

\section{Mahasiswa}

Menurut Undang-undang Republik Indonesia No. 12 Tahun 2012 tentang Pendidikan Tinggi, mahasiswa adalah peserta didik pada jenjang pndidikan tinggi. Bagi mahasiswa, menjadi seseorang yang masuk dalam civitas di akademika maka dirinya akan berada dalam posisi seorang insan yang dewasa dimana memiliki intelektual yang profesional. Dimana dalam hal ini kampus menjadi sebuah wadah bagi mahasiswa untuk berproses sehingga mendapat julukan"maha"siswa.

Hartaji (2012)Mahasiswa adalah seseorang yang sedang dalam proses menimba ilmu ataupun belajar dan terdaftar sedang menjalani pendidikan pada salah satu bentuk perguruan tinggi yang terdiri dari akademik, politeknik, sekolah tinggi, institut dan universitas . sedangkan menurut Siswoyo (2007)mahasiswa dapat didefinisikan sebagai individu yang sedang menuntut ilmu ditingkat perguruan tinggi, baik negeri maupun swasta atau lembaga lain yang setingkat dengan perguruan tinggi. Mahasiswa dinilai memiliki tingkat intelektualitas yang tinggi, kecerdasan dalam berpikir dan kerencanaan dalam bertindak. Berpikir kritis dan bertindak dengan cepat dan tepat merupakan sifat yang cenderung melekat pada diri setiap mahasiswa, yang merupakan prinsip yang saling melengkapi.

Menurut Yusuf (2012) Seorang mahasiswa dikategorikan pada tahap perkembangan yang usianya 18 sampai 25 tahun. Tahap ini dapat digolongkan pada masa remaja akhir sampai masa dewasa awal dan dilihat dari segi perkembangan, tugas perkembangan pada usia mahasiswa ini ialah pemantapan pendirian hidup.

3.

\section{ata kuliah kewirausahaan}

Serian Wijatno (2004) Di Indonesia pendidikan entrepreneurship mulai digalakkan pada tahun 2000-an oleh Direktorat Jendral Pendidikan Tinggi mendorong berkembangnya pendidikan entrepreneurship, diantaranya melalui pendanaan kegiatan mahasiswa dalam bidang entrepreneurshi. Menurut Basrowi (2011) pendidikan kewirausahaan adalah pendidikan yang menerapkan prinsip-prinsip dan metodologi kearah pembentukan kecakapan hidup (life skill) pada peserta didiknya melalui kurikulum yang dikembangkan di perguruan tinggi.

Pendidikan kewirausahaan atau entrepreneurship akan semakin digalakkan di perguruan tinggi agar lulusan perguruan tinggi mampu mandiri. Pendidikan kewirausahaan di perguruan tinggi diharapkan bisa menyiapkan mahasiswa untuk berani mandiri, tidak lagi terfokus menjadi pencari kerja. Apalagi data pengangguran terdidik di Indonesia menunjukkan, semakin tinggi pendidikan seseorang, semakin rendah kemandirian dan semangat kewirausahaannya.

\section{METODE PENELITIAN}


Penelitian dilaksanakan di Prodi Pendidikan Pancasila dan Kewarganegaraan Fakultas Pendidikan dn Ilmu Pengetahuan Sosial IKIP PGRI Bojonegoro. Penelitian dilakukan dengan metode wawancara menggunakan pertanyaan sebagai instrumenutama dalam mengumpulkan data primer. Data primer diperoleh dari informan yaitu mahasiswa Program Studi Pendidikan Pancasila dan Kewarganegaraan yang telah mengambil mata kuliah kewirausahaan di tahun 2018-2020 Peneliti menggunakan metode purposive sampling untuk menentukan siapa yang menjadi informan penelitian. Untuk mendapat informasi yang relevan, maka peneliti meminta informan untuk menjawab pertanyaan wawancara yang diajukan guna mendapat informasi tentang variabel-variabel yang diteliti. Untuk menguji keabsahan data peneliti menggunakan teknik trianggulasi sumber dan melakukan member check. Teknik analisis data dengan cara pengumpulan data, reduksi data , penyajian data serta penarikan kesimpulan (Lexy J, Meleong, 2013).

\section{HASIL DAN PEMBAHASAN}

\section{Menumbuhkan Jiwa entrepreneur Mahasiswa PPKN Melalui Mata Kuliah Kewirausahaan}

Dasar penyelenggaraan mata kuliah kewirausahaan ini karena Kementrian Pendidikan Nasional sendiri mengutamakan pendidikan kewirausahaan sejak tahun 1997. Pada tahun 1997 Direktorat Penelitian dan Pengabdian kepada masyarakat,DITLITABMAS merealisasikan PBKT yaitu program Pengembangan Budaya Kewirausahaan di Perguruan Tinggi (DITLITABMAS, 2011).

Peraturan Pemerintah No.17/2010:61-62) bagaimana Perguruan Tinggi menghasilkan lulusan dengan berbagai profesi. Pendidikan tinggi bertujuan (1) membentuk insan yang (a) beiman dan bertakwa kepada Tuhan Yang Maha Es,berakhlak mulia, dan berkepribadian luhur ;(b) sehat, berilmu, dan cakap; (c) kritis, kreatif,inovatif, mandiri, percaya diri dan berjiwa wirausaha; serta (d) toleransi,peka sosial dan lingkungan, demokratis, dan bertanggung jawab dan (2) menhasilkan produk-produk ilmu pengetahuan, teknologi, seni, atau olahraga yang memberikan kemaslahatan bagi masyarakat, bangsa, negara, umat, manusia, dan lingkungan.

Berdasarkan analisis yang sudah dilakukan oleh peneliti terhadap data hasil dari observasi dan wawancara, maka mata kuliah kewirausahaan sangatlah penting dan memiliki kontribusi dalam mempersiapkan mahasiswa calon guru sekaligus menumbuhkan jiwa entrepeneur dari dalam diri mahasiswa.

Selain pengembangan mata kuliah hukum pidana dan hukum perdata melalui praktik pemahaman hukum di Pengadilan Negeri yang dilaksanakan oleh mahasiswa program studi PPKN ,maka mata kuliah kewirausahaan juga sangat penting bagi mahassiswa program studi. pertama,menanamkan pengetahuan dan minat dalam berwirausaha. Menurut Puspitaningsih (2014 ) minat berwirausaha merupakan prediktor terbaik untuk perilaku berwirausaha. Pengetahuan kewirausahaan merupakan sebuah bentuk informasi dari hasil pengalaman belajar yang sudah dialami, melalui daya ingat seseorang memulai untuk berproses tentang bagaimana melakukan sebuah usaha sehingga hal tersebut menyebabkan akan timbulnya serta munculnya sebuah keberanian untuk mengambil resiko dan mampu berfikir logis dalam menangani suatu usaha yang dilakukan. Minat mahasiswa untuk berwirausaha merupakan keinginan seseorang untuk bekerja keras dan berani untuk memenuhi kebutuhan hidupnya tanpa takut dibayangbayangi akan suatu resiko yang akan terjadi. Secara garis besar bahwasanya minat untuk berwirausaha dikarenakan suatu pengetahuan akan pentingnya berwirausaha, hal ini berlanjut kepada suatu kegiatan yang akan dilakukan. Peran dosen sangat berarti dalam memberikan mata kuliah kewirausahaan bagi mahasiswa program studi PPKN. Menurut 
Ulfa dan Maftukhatusolikhah (2015) minat berwirausaha tidaklah dimiliki begitu saja oleh seseorang, melainkan dapat dipupuk dan dikembangkan.

Kedua, menumbuhkan kepercayaan diri dan keterampilan dalam berwirausaha. Menurut Wikanso (2013) beberapa keterampilan yang harus dimiliki itu diantaranya, keterampilan kreatif dalam menciptakan nilai tambah, keterampilan dalam memimpin dan mengelola, keterampilan berkomunikasi dan berinteraksi, dan keterampilan teknik dalam bidang usaha yang dilakukan. Kepercayaan diri pada mahasiswa perlu dibangun dan ditanamkan sehingga mahasiswa setelah lulus dari perguruan tinggi tidak sibuk mencari pekerjaan namun akan sibuk membuka lapangan pekerjaan, kepercayaan diri berhubungan dengan adanya keterampilan. Keterampilan pada mahasiswa akan terlihat disaat mahasiswa sudah mampu menunjukkan kepercayaan dirinya dalam berwirausaha.

Ketiga, meningkatkan motivasi untuk menjadi young entrepreneur. Menurut Rosmiati dkk(2015) motivasi adalah suatu dorongan dari dalam diri seseorang yang mendorong orang tersebut untuk melakukan sesuatu, termasuk menjadi young entrepreneur. Peneliti menemukan dan mengemumukan bahwasannya adanya mata kuliah kewirausahaan telah memberikan motivasi bagi mahasiswa untuk menjadi pengusaha muda dimana untuk menjadi pengusaha muda dimulai dari usia muda, jadi mata kuliah kewirausahaan bukan hanya sekedar teori saja namun memiliki sebuah dukungan berupa kegiatan yang dikemas secara menarik, yakni memberikan kesempatan bagi setiap mahasiswa untuk mengikuti PKM (Program Kreativitas Mahasiswa).

\section{KESIMPULAN DAN SARAN}

\section{Simpulan}

Mata kuliah kewirausahaan adalah mata kuliah yang mampu membangun jiwa entrepeneur mahasiswa, dalam mata kuliah kewirausahaan ini mahasiswa akan mendalami tentang sebuah proses berwirausaha. Bagi mahasiswa program studi PPKN mata kuliah kewirausahaan sangatlah menunjang karena dengan adanya mata kuliah ini mahasiswa tertanam pengetahun dan wawasan berwirausaha,menumbuhkan kepercayaan diri dan keterampilan dalam berwirausaha dan meningkatkan motivasi untuk menjadi young entrepeneur. Memberikan kesempatan bagi mahasiswa untuk mengikuti PMK adalah salah satu bentuk dukungan.

\section{Saran}

Dengan mengadakan safari ke tempat-tempat usaha kecil akan membuat mahasiswa termotivasi untuk memulai berwirausaha di usia muda.

\section{DAFTAR PUSTAKA}

[1] Anwar, Muhammad. (2014). Pengantar Kewiraushaan Teori dan Aplikasi. Ed 1. Jakarta. Prenadamedia Group.

[2] Basrowi. (2011) . Kewirausahaan untuk Perguruan Tinggi. Bogor. Ghalia Indonesia

[3] BPS. (2020). Keadaan Ketenagakerjaan Jawa Timur tahun 2020. Diakses tanggal 13 maret 2020 pukul 20.00

[4] Farid. (2017). Kewirausahaan Syaria.Jakarta. Kencana.

[5] Handayani. Tri, Suyanto. ( 2016). Hubungan EQ, Pengetahuan kewirausahaan, dan hasrat marginal menabung, dengan motivasi berwirausaha mahasiswa Pendidikan Ekonomi. Jurnal Harmoni sosial : Jurnal Pendidikan IPS. Volume 3, No 1, (pp. 95-104). 
[6] Hartaji, Damar A. (2012). Motivasi Berpretasi Pada Mahasiswa yang Berkuliah dengan Jurusan Pilihan Orangtua. Fakultas Psikologi Universitas Gunadarma. (tidak dipubliksikan).

[7] Moko P. Astameon. (2008). Entrepreneurship Dalam Perspektif Kondisi Bangsa Indonesia. Bandung. Alfabeta.

[8] Meleong. J, Lexy. (2013). Metodologi Penelitian Kualitatif. Edisi Revisi. Bandung. PT Remaja Rosdakarya.

[9] Kasmir. (2011). Kewirausahaan. Jakarta.Rajawali Press

[10] Panji Anorga dan Joko Sudantoko (2002). Koperasi: Kewirausahaan Dan Pengusaha Kecil. Jakarta . Rineka Cipta.

[11] Peraturan Pemerintah. (2010). Peraturan Pemerintah Nomor 17 tahun 2010 Tentang Pengelolaan Dan Penyelenggaraan Pendidikan.

[12] Puspitaningsih, Flora. (2014). Pengaruh Efikasi Diri dan Pengetahuan Kewirausahaan Terhadap Minat Berwirausaha Melalui Motivasi. Tulunggaungng: STKIP PGRI, dalam Jurnal Ekonomi dan Kewirausahaan Vol. 2. No. 2.

[13] Rosmiati, dkk .(2015). Sikap, Motivasi, dan Minat Berwirausaha Mahasiswa.Nusa Tenggara Timur: Politeiteknik Negeri Kupang, dalam Jurnal Manajemen dan Kewirausahaan Vol.2.No. 2.

[14] Saiman, Leonardus. (2014). Kewirausahaan : Teori, Praktik dan Kasus-kasus edisi2. Jakarta. Salemba Empat .

[15] Serian Wijatno. (2004). Pengantar Entrepreneurship.Jakarta.Gramedia.

[16] Siswoyo, D., dkk. (2007). Ilmu Pendidikan. Yogyakarta: UNY Press.

[17] Ulfa, Nadhira dan Maftukhatusolikhah. (2015). Minat Wirausaha Kaum Santri dan Faktor-faktor Yang Mempengaruhinya (Studi Pada Pondok Pesantren Ar-Riyadh Palembang) :Universitas Islam Negeri Raden Fatah, dalam Jurnal I-Economics Journal, Vol.1. No. 1. 